\title{
Influence of irrigation and hydrogel application on yield and economics of pearl millet (Pennisetum glaucum L.) under Eastern UP condition
}

\author{
Sumit Ray 函 \\ Department of Agronomy, Naini Agricultural Institute , Sam Higginbottom University of Agriculture, Technology and Sciences, Prayagraj \\ Umesha C. \\ Department of Agronomy, Naini Agricultural Institute , Sam Higginbottom University of Agriculture, Technology and Sciences, Prayagraj \\ M. R. Meshram \\ Department of Agronomy, Naini Agricultural Institute , Sam Higginbottom University of Agriculture, Technology and Sciences, Prayagraj \\ Lalit K. Sanodiya \\ Department of Agronomy, Naini Agricultural Institute , Sam Higginbottom University of Agriculture, Technology and Sciences, Prayagraj
}

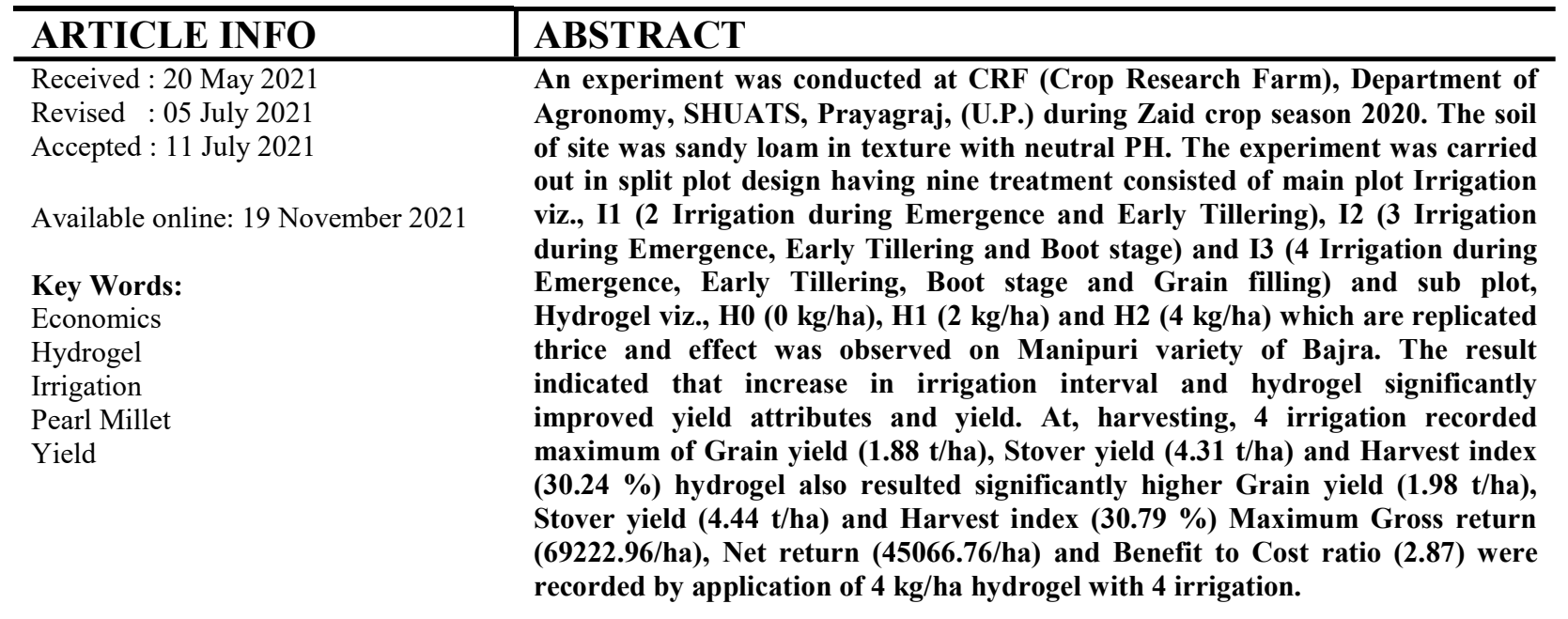

\section{Introduction}

India is the largest producer of bajra, during 202021 about 65.15 lakh ha (160.99 lakh acres) area was covered under bajra. The states of Rajasthan 38.42 lakh ha (94.94 lakh acres), Uttar Pradesh 9.20 lakh ha (22.73 lakh acres), Maharashtra 6.14 lakh ha (15.17 lakh acres), Haryana 4.32 lakh ha (10.67 lakh acres), Madhya Pradesh 3.05 lakh ha (7.54 lakh acres), Karnataka 1.45 lakh ha (3.58 lakh acres) and Gujarat 1.81 lakh ha (4.47 lakh acres) are the major growers of bajra in India. According to the 3rd advance estimates for 2019-20 bajra production estimate was 10.31 million tonnes as against 8.66 million tonnes in 2018-19. (Department of Food and Public Distribution 2020-
21). Water through irrigation is already scarce and the world is researching on water efficient agriculture. Increasing food demand and declining water resources are challenges for food security (Cookson et al., 2001). The issue of water management has assumed paramount importance and occupied the centre stage of politico-economic debates in the world. Scheduling irrigation on the basis of evaporative demand results not only in efficient utilization of water but also in considerable saving of water. New methods in soil science and water are using hydrogels as reservoirs, prevention from water wastage and increase of irrigation efficiency (Bedi et al., 2004). Hydrogel is 
a hydrophilic polymer which is a cross-link of networks capable of holding large amounts of water as well as biological fluids. When the soil is applied with hydrogel, water holding capacity of soil increases significantly and when nearby soil dries, the stored water is released slowly back to the soil. These synthetic polymers crystalline in form and that they are marketed as super absorbent, hydrogel, aquasorb etc. this products shows a swelling potentials of 300 time, mostly exceeding 500 times its weight. Swelling ratio increases with the increase in temperature up to $50^{\circ} \mathrm{C}$ with none adverse effect on the polymer matrix structure (Khodadadi et al., 2016).

\section{Material and Methods}

The research was conducted during Zaid crop season, 2020 at CRF (Crop Research Farm), Department of Agronomy, Sam Higginbottom University of Agriculture, Technology and Science (SHUATS), Prayagraj (Allahabad) (UP). The CRF is situated at $25.57^{\circ} \mathrm{N}$ latitude, $87.19^{\circ} \mathrm{E}$ longitude and at an altitude of $98 \mathrm{~m}$ above mean sea level. It is situated on the right side of the river Yamuna and by the opposite side of Prayagraj City.The research was carried out in split plot design, replicated thrice. The treatment comprised of 3 Irrigation interval based on crop growth stages,( during Emergence, Early Tillering, Boot stage and Grain filling ) and noted as I1 (2 Irrigation during Emergence and Early Tillering), I2 (3 Irrigation during emergence, early tillering and boot stage) and I3 (4 Irrigation during Emergence, Early Tillering, Boot stage and Grain filling) assigned as main plot. Each main plot was further divided into 3 sub plots, i.e. Hydrogel levels $\mathrm{H} 0 \quad(0 \mathrm{~kg} / \mathrm{ha}$ Hydrogel), H1 (2 kg/ha Hydrogel), H2 (4 kg/ha Hydrogel) through surface application and the possible combination is presented in Table 1 with details of pearl millet crop. During the growing season, the mean weekly maximum and minimum temperature, relative humidity and rainfall were $36.60{ }^{\circ} \mathrm{C}, 24.90{ }^{\circ} \mathrm{C}, 76.40 \%, 48.48 \%$ and $4.72 \mathrm{~mm}$ respectively.

Bajra was sown at a spacing of $40 \times 10 \mathrm{~cm}$ at a seed rate of $6-8 \mathrm{~kg} / \mathrm{ha}$. The field was irrigated before one day of sowing and further irrigated based on treatment. The RDF i.e Nitrogen (60 $\mathrm{kg} / \mathrm{ha}$ ) was supplied through urea and DAP in two equal splits, first as basal and second at 45 DAS (days after sowing), whereas full dose of $\mathrm{P}_{2} \mathrm{O}_{5}$ (40 $\mathrm{kg} / \mathrm{ha})$ and $\mathrm{K}_{2} \mathrm{O}(40 \mathrm{~kg} / \mathrm{ha})$ was applied through DAP and MOP. Hydrogels were applied in each plots according to the treatments before sowing of seed along with fertilizers during first split as basal. Observations on growth parameters, yield attributes and yield of Bajra, was recorded and significance was analysed by the variance ratio. (F-value) at $5 \%$ level (Gomez and Gomez, 1984). Relative economics was calculated as per the prevailing market prices of the inputs and produced during Zaid season.

Table 1: Treatment combinations.

\begin{tabular}{|c|c|}
\hline Treatments & Treatment Combination \\
\hline I1 H0 & 2 irrigation (6 DAS and 27 DAS) with $0 \mathrm{~kg} / \mathrm{ha}$ of Hydrogel \\
\hline $\mathrm{I} 2 \mathrm{H} 0$ & 3 irrigation (6 DAS, 27 DAS and 47 DAS) with $0 \mathrm{~kg} / \mathrm{ha}$ of Hydrogel \\
\hline I3 H0 & 4 irrigation (6 DAS, 27 DAS, 47 DAS and 62 DAS) with $0 \mathrm{~kg} / \mathrm{ha}$ of Hydrogel \\
\hline I1 H1 & 2 irrigation (6 DAS and 27 DAS) with $2 \mathrm{~kg} / \mathrm{ha}$ of Hydrogel \\
\hline I2 H1 & 3 irrigation (6 DAS, 27 DAS and 47 DAS) with $2 \mathrm{~kg} / \mathrm{ha}$ of Hydrogel \\
\hline I3 H1 & 4 irrigation (6 DAS, 27 DAS, 47 DAS and 62 DAS) with $2 \mathrm{~kg} /$ ha of Hydrogel \\
\hline $\mathrm{I} 1 \mathrm{H} 2$ & 2 irrigation (6 DAS and 27 DAS) with $4 \mathrm{~kg} / \mathrm{ha}$ of Hydrogel \\
\hline $\mathrm{I} 2 \mathrm{H} 2$ & 3 irrigation (6 DAS, 27 DAS and 47 DAS) with $4 \mathrm{~kg} /$ ha of Hydrogel \\
\hline $\mathrm{I} 3 \mathrm{H} 2$ & 4 irrigation (6 DAS, 27 DAS, 47 DAS and 62 DAS) with $4 \mathrm{~kg} /$ ha of Hydrogel \\
\hline
\end{tabular}

Emergence-6 DAS, Early tillering-27 DAS, Boot stage-47 DAS, Grain filling-62 DAS

Results and Discussion

Growth parameter

Growth parameters of pearl millet, viz. Plant height $(\mathrm{cm})$ and Dry weight $(\mathrm{g})$ varied because of different irrigation interval and hydrogel level are presented in Table 2. The treatment receiving 4 irrigation (I3) resulted in higher plant height (182.34 $\mathrm{cm})$ and Dry weight $(128.33 \mathrm{~g})$. In the above treatment, I3, was recorded significantly 
Table 2: Effect of Hydrogel and Irrigation on Yield of pearl millet

\begin{tabular}{|c|c|c|c|c|c|c|c|c|c|c|c|c|c|c|c|}
\hline \multirow{3}{*}{ Levels } & \multicolumn{6}{|c|}{ Plant Height (cm.) } & \multicolumn{6}{|c|}{ Dry Weight (g/plant) } & \multicolumn{3}{|c|}{ Yield } \\
\hline & \multicolumn{6}{|c|}{ Days After Sowing (DAS) } & \multicolumn{6}{|c|}{ Days After Sowing (DAS) } & \multirow{2}{*}{$\begin{array}{l}\text { Grain } \\
\text { Yield } \\
(\mathrm{t} / \mathrm{ha})\end{array}$} & \multirow{2}{*}{$\begin{array}{c}\text { Stover } \\
\text { Yield }\end{array}$} & \multirow{2}{*}{$\begin{array}{c}\text { Harvest } \\
\text { Index } \\
(\%) \\
\end{array}$} \\
\hline & 15 & 30 & 45 & 60 & 75 & 90 & 15 & 30 & 45 & 60 & 75 & 90 & & & \\
\hline \multicolumn{16}{|c|}{ IRRIGATION (No.) } \\
\hline 2 Irrigation & 3.2 & 12.21 & 60.57 & 120.86 & 153.38 & 161.41 & 1.03 & 3.64 & 23.55 & 48.44 & 76.86 & 111.83 & 1.59 & 4.07 & 28.02 \\
\hline 3 Irrigation & 3.28 & 13.3 & 55.69 & 125.37 & 160.92 & 169.15 & 1.04 & 4.83 & 26.88 & 53.49 & 87.43 & 120.89 & 1.71 & 4.13 & 29.11 \\
\hline 4 Irrigation & 3.14 & 10.53 & 51.72 & 135.49 & 173.89 & 182.34 & 0.81 & 3.36 & 33.66 & 54.39 & 93.9 & 128.33 & 1.88 & 4.31 & 30.24 \\
\hline S.E (d) & 0.12 & 1.42 & 3.88 & 5.71 & 4.65 & 4.86 & 0.168 & 0.488 & 0.232 & 1.675 & 1.352 & 1.48 & 0.032 & 0.042 & 0.453 \\
\hline C.D at 5\% & - & - & - & - & 7.46 & 7.79 & - & - & 0.372 & 2.685 & 2.167 & 2.37 & 0.052 & 0.067 & 0.726 \\
\hline \multicolumn{16}{|c|}{ HYDROGEL (kg/ha) } \\
\hline Hydrogel 0 kg ha-1 & 3.04 & 11.06 & 44.86 & 110.58 & 145.36 & 153.49 & 0.96 & 3.28 & 25.53 & 49.25 & 80.31 & 114.09 & 1.47 & 3.88 & 27.55 \\
\hline Hydrogel 2 kg ha-1 & 3.49 & 12.34 & 50.97 & 126.36 & 162.9 & 171.25 & 0.86 & 3.45 & 28.1 & 51.74 & 86.65 & 119.81 & 1.72 & 4.19 & 29.03 \\
\hline Hydrogel 4 kg ha-1 & 3.09 & 12.64 & 72.16 & 144.78 & 179.93 & 188.15 & 1.05 & 5.1 & 30.46 & 55.33 & 91.22 & 127.14 & 1.98 & 4.44 & 30.79 \\
\hline S.E (d) & 0.14 & 0.26 & 4.99 & 7.26 & 5.67 & 5.78 & 0.126 & 0.432 & 0.534 & 0.786 & 1.868 & 2.04 & 0.041 & 0.041 & 0.375 \\
\hline C.D at $5 \%$ & 0.3 & 0.57 & 10.87 & 15.81 & 12.36 & 12.59 & - & 0.941 & 1.164 & 1.712 & 4.071 & 4.45 & 0.09 & 0.09 & 0.817 \\
\hline
\end{tabular}


Table 3: Effect of Irrigation and hydrogel on Economics of pearl millet

\begin{tabular}{|c|c|c|c|c|}
\hline \multirow[b]{2}{*}{ TREATMENT } & \multicolumn{4}{|c|}{ ECONOMICS } \\
\hline & $\begin{array}{c}\text { COST OF CULTIVATION } \\
\text { (INR) }\end{array}$ & $\begin{array}{c}\text { GROSS RETURN } \\
\text { (INR) }\end{array}$ & $\begin{array}{c}\text { NET RETURN } \\
\text { (INR) }\end{array}$ & B : C RATIO \\
\hline 2 IRRIGATION & 18556.2 & 51260 & 32703.8 & 1.76 \\
\hline 3 IRRIGATION & 19556.2 & 54140 & 34583.8 & 1.77 \\
\hline 4 IRRIGATION & 20556.2 & 58600 & 38043.8 & 1.85 \\
\hline HYDROGEL 0 kg ha-1 & 16556.2 & 47860 & 31303.8 & 1.89 \\
\hline HYDROGEL 2 kg ha-1 & 18356.2 & 54600 & 36243.8 & 1.97 \\
\hline HYDROGEL 4 kg ha-1 & 20556.2 & 61320 & 40763.8 & 1.98 \\
\hline \multicolumn{5}{|l|}{ INTERACTION } \\
\hline 3 IRRIGATION + HYDROGEL 0 kg/ha & 19556.20 & 48815.93 & 29259.73 & 1.50 \\
\hline 3 IRRIGATION + HYDROGEL 2 kg/ha & 21356.20 & 56342.74 & 34986.54 & 1.64 \\
\hline 3 IRRIGATION + HYDROGEL 4 kg/ha & 23156.20 & 62217.04 & 39060.84 & 1.69 \\
\hline 4 IRRIGATION + HYDROGEL 0 kg/ha & 20556.20 & 51608.00 & 31051.80 & 1.51 \\
\hline 4 IRRIGATION + HYDROGEL 2 kg/ha & 22356.20 & 60715.85 & 38359.65 & 1.72 \\
\hline 4 IRRIGATION + HYDROGEL 4 kg/ha & 24156.20 & 69222.96 & 45066.76 & 1.87 \\
\hline
\end{tabular}


higher plant height $(\mathrm{cm})$ and Dry weight $(\mathrm{g})$. While increasing dose of Hydrogel $(\mathrm{H} 2)$ also contributed significantly higher plant height $(188.15 \mathrm{~cm})$ and Dry weight $(127.14 \mathrm{~g})$. Pre soil analysis showed available N, P and $\mathrm{K}$ as $187 \mathrm{~kg}$ ha-1, $12.9 \mathrm{~kg}$ ha- 1 and $186 \mathrm{~kg}$ ha-1 respectively whereas post soil analysis revealed available $\mathrm{N}, \mathrm{P}$ and $\mathrm{K}$ as $203.7 \mathrm{~kg}$ ha-1, $17.2 \mathrm{~kg}$ ha-1 and $208.8 \mathrm{~kg}$ ha- 1 respectively. The increase in the plant height and may be due to supply of soil moisture around the root zone, which provided suitable micro environment for uptake and translocation of the nutrients which finally resulted in plant growth and development. (Saini et al., 2018). Dry matter production means production of dry matter over a certain period of time which is essential for supply of photosynthates to sink. Significantly higher dry matter production was recorded in soil treated with hydrogel at different stages of crop. This concludes that hydrogel resulted in more dry matter production. Hydrogel increases water holding capacity of soil and nutrient supplying capacity of soil which finally increases growth and dry matter production (Saini et al., 2016)

\section{Yield}

Grain as well as stover yield varied significantly because various irrigation interval and application of 4 irrigation (I3) recorded up to $18.2 \%$ and $9.9 \%$ higher grain yield than that of 2 irrigation (I1) and 3 irrigation (I2) respectively. Stover yield significantly higher under 4 irrigation (I3) (4.31 $\mathrm{t} / \mathrm{ha})$. In case of hydrogel, $4 \mathrm{~kg} / \mathrm{ha}$ hydrogel application recorded significantly higher grain yield which fetched $34.6 \%$ more over no hydrogel application. Similar findings recorded in Stover yield due to application of hydrogel $4 \mathrm{~kg} / \mathrm{ha}$ (4.44 t/ha) produced more biomass significantly over other hydrogel application. The higher seed and stover yields could be attributed to increased soil moisture coupled with accelerated nutrients uptake, which helped the plant to put optimum growth. Increase in seed and stover yields with an application of irrigation was reported by Fallahi et al. (2015). The harvest index of pearl millet was increased by irrigation and hydrogel levels. As a well-established fact harvest index is more or less governed by genetic makeup of a plant and is not influenced much more by input supply system if crop is raised under recommended practices (Saini et al., 2020).

\section{Economics}

Economics includes cost of cultivation (INR), Gross return (INR), Net return (INR), and B: C Ratio. Least cost of cultivation was observed in 2 irrigation and 0 hydrogel $\mathrm{kg} / \mathrm{ha}$ but, highest Gross return (INR 69222.96/ha), Net return (INR 450066.76/ha) and B: C Ratio (1.87) was recorded in 4 irrigation and 4 hydrogel $\mathrm{kg} / \mathrm{ha}$ in table 3.whereas B: C Ratio (1.67), Net return (INR 66011/ha) was observed in treatment applied with 5 $\mathrm{kg}$ of hydrogel per ha and I3 (1.2 IW: CPE) (Saini et al., 2020). Economics of different treatments changes according to availability of irrigation and hydrogel and other resources to the farmer.

\section{Conclusion}

Pearl millet is mostly grown in arid and semi-arid regions. Hydrogel application and irrigation intervals during different critical stage of crop provide better growth and yield. It was observed that application of hydrogel and irrigation at different critical stages resulted in better plant height, dry weight, grain and stover yield in comparison to control. All these factors finally lead to increase in gross and net return. Some further study can also be done on different crops along with different dose of hydrogel and different irrigation management.

\section{Acknowledgement}

Author express gratitude to my advisor Dr. Umesha, C. and all the faculty members of Department of Agronomy for constant support and guidance to carry out the whole experimental research study.

\section{References}

Bedi, K. J., \& Sohrab, F. (2004). Evaluation of super absorbent polymer application on water holding capacity and potential in three soil type. Journal of Science and polymer Technology, 3, 163-173.
Cookson, P., AbdelRahman, H., \& Hirsbrunner, P. (2001). Effect of Hydrophobic Polymer Application and Irrigation Rates on Yield of Field Grown Okra. Journal of Agricultural and Marine Sciences [JAMS], 6, 67-75. 
Ray et al.

Khodadadi Dehkordi, D. (2016). The Effects of Superabsorbent Polymers on Soils and Plants. Pertanika Journal of Tropical Agricultural Science, 39(3).

Department of Food \& Public Distribution (2017-18), Area production and productivity of different crops in India 2020-21

Fallahi, H.R., Kalantari, R.T, Shajari, M.A., \& Soltanzadeh, M.G. (2015). Effect of super absorbent polymer and irrigation deficit on water use efficiency, growth and yield of cotton. Notulae Scientia Biologicae, 7(3), 338-344.
Gomez, K. A., \& Gomez, A. A. (1984). Statistical procedures for agricultural research. John Wiley \& Sons.

Saini, A. K., Patel, A. M., Chaudhary, P. P., \& Saini, L. H. (2018). Impact assessment of irrigation, fertility and hydrogel levels on growth attributes, yield and economics of summer pearl millet (Pennisetum glaucum L.) under North Gujarat conditions. J. Pharm. Phytochem, 7, 29142918.

Saini, A. K., Patel, A. M., Saini, L. H., \& Malve, S. H. (2016). Growth, phenology and yield of summer Pearl millet (Pennisetum glaucum L.) as affected by varied application of water, nutrients and hydrogel. 